\title{
Analysis of the Relationship between Chinese Banking Competition and Risk-taking an Empirical Study Based PR Model
}

\author{
Lin Ji, Lihong Guo \\ Xi'an University of Technology, XI'AN, 710054, China
}

\begin{abstract}
In this paper, the main research perspective is the relationship between Chinese banking competition and risktaking, and use of non-structural method of PR models to analysis China 14 banks from 1997 to 2008 data samples to explore the degree of banking market competition empirical analysis and the relationship between banking competition and the risk. The results show that: the state of China's banking industry is monopolistic competition; there is a significant relationship between banking competition and risk-taking, and the degree of competition in the banking sector and the banks' bad loans showed a positive correlation between the proportion; it is different that the impact of exposure levels of degree of competition in the banking sector on the individual bank, and banking competition will lead to state-owned banks (large banks) to take greater risks. Therefore, the article suggested the bank should further promote the reform of the good market access barrier, improve the effectiveness of banking supervision.
\end{abstract}

Keywords-banking competition; risk-taking; PR model; banking supervision.

\section{INTRODUCTION}

From the trend of development of the banking sector in Western countries, on the one hand, banking deregulation, competition significantly enhanced; on the other hand, after several mergers and acquisitions in the banking market monopoly further intensified competition among banks weakened. In the context of economic liberalization and financial globalization, China has achieved full liberalization of the banking sector, with the entry of Chinese joint-stock reform of the banking sector and foreign banks in depth, more intense competition among banks. This not only brings vitality to China's banking sector, while also increasing the risk of excessive competition in the banking sector commitments. In view of this, we use the non-structural method of PR models to China 14 banks from 1997 to 2008 data samples to empirical analysis Chinese banking market competition and use panel data model on the basis of analysis of the relationship banking competition between the degrees of risk.

The article is organized as follows: The first part is related research under review, the second part is banking competition measure, the third part analysis the relation between banking competition and the degrees of risk, and the fourth part is the conclusion of the analysis and policy recommendations.

\section{RELATED WORK}

Empirical research on the banking industry to foreign competition and risk-taking has two main aspects: First, bank competition and risk transfer. Keeley (1990) believe that the United States led to bank failures occurred in part because of increased competition in the banking market lies between the $1980 \mathrm{~s}$, which has eroded the bank's monopoly rents, reducing the value of the license. Reduce the incentive to increase the value of permits banks to take risks, the value of the license and bank capital positively correlated negatively correlated with bank risk. Demestz et al [1] on the basis of Keeley on different ways to measure bank risk, also found that the correlation between the value of the license and bank capital and risk. Salas and Saurina [2] applied the same method of testing the Spanish banking system, the higher the value associated with the issuance of the permit low credit risk. Petersen and Raian investigated the use of U.S. data relational theory loans they made, they used to indicate the degree of market concentration and market power, and found in a highly concentrated market, the newly established enterprises more competitive than in obtained on credit markets to more ; and also found in high concentration in the market, the bank will charge interest to smooth the way to the enterprise, that enterprise is a new phase when the levy lower interest rates, while enterprises in the mature stage, the bank will charge higher interest rates.

Cetorelli and Gambera [3] uses a cross-border, crossindustry data to test market concentration on economic growth, found that in general, the impact of concentration on economic growth is negative, but specific to the growth of different industries, different effects brought about concentration. For the newly established industries rely more on bank loans, if the country a higher degree of concentration in the banking system, its growth rate is faster. This evidence also supports the view of relationship lending. Beck et al[4]defined as bank fragility of the banking crisis erupted. They looked at 79 countries panel data from 1980 to 1997 , to the probability of a banking crisis as a dependent variable, bank concentration and a series of macroeconomic and structural variables as explanatory variables, using Logit model to estimate the probability, find bank concentration and the probability of a banking crisis was a significant negative correlation of the new bank 's access restrictions will significantly increase the probability of a 
banking crisis, which could allow them to raise as a single measure of the concentration of market power indicator questioned.

De Nicolo[5] adopted a new empirical method, and draw evidence to the contrary. They found that the probability of bank accounts with banks down individual concentration was significantly positively correlated, which means that other things being equal, in highly concentrated markets banks more vulnerable. Boyd et al [6] for further banking competition on bank exposures empirical study, they found that the relationship between competition and the risk is mixed.

Domestically, there is no specific empirical research on banking competition and exposures. In this regard, we have a big gap with foreign countries, but the Chinese banking sector has its own characteristics in terms of institutional mechanisms, cannot simply be directly applied research abroad, but should be based on empirical research, and detailed analysis of the relationship China's banking sector competition and risk-taking.

\section{THE MEASURE OF BANKING COMPETITION}

\section{A. PR Model to Measure Banking Competition}

There are two main structural and non- structural methods to measure banking competition. Theory of industrial organization structure method is to measure the structure of the market, through a pointer to reflect the external structure of the banking market, and thus indirectly reflects the level of competition on the market. Structure method is widely used in the banking industry in the early research. Emergence and development of the non- structural approach stems from the new empirical industrial organization research methods. The main methods include : Iwata mode; Bresnahan and Lau model, referred to as BL model; Panzar and Rosse model, referred to as the PR model. Non-structural method to measure competition is mainly to compensate for the lack of structural theory and empirical research on competition measure, this approach to measure competition analysis emphasizes the bank's competitive behavior, rather than simply using the market structure on the external information. In the actual process of theoretical and empirical research, because the model does not have the empirical research Iwata conditions, only Shaffer and Disalvo (1994) research on the use of over- the duopoly market once the bank, while the model is widely used BL model and PR model. BL model is not consistent with the means to achieve the PR model though, but its inherent mechanism to measure the degree of market competition is consistent with that estimated by the degree of departure from competitive prices to measure competition within the industry vendors. Study of the banking industry competition also mostly using both methods, this paper will use the PR model banking competition measure. Relative to the advantage BL model, PR models include: model output using income indicators, rather than price index, so the data is more readily available ; PR model using vendor data , taking into account the individual characteristics of vendors, to make the model covers more comprehensive information ;
PR model does not need to make the definition of the product market, thus reducing errors due to errors caused by market definition, $\mathrm{H}$ test statistic reflects the average competitive market characteristics .

PR model assumes that under different market structures, the bank will put the changes in commodity prices take a different pricing strategy, therefore, through the analysis of total banking income elasticity of input prices can determine the degree of competition in the banking market in which. Model as follows:

When $\mathrm{i}$ banks to maximize profits, marginal revenue equals marginal cost

$$
R_{i}\left(\mathrm{Xi}, \mathrm{n}, \mathrm{Zi}_{\mathrm{i}}\right)-C_{i}\left(\mathrm{X}, \mathrm{W}_{\mathrm{i}}, \mathrm{t}_{\mathrm{i}}\right)=0
$$

$R_{i}$ on behalf of the bank's marginal revenue, $C_{i}$ on behalf of the bank's marginal cost, $\mathrm{Xi}$ means that the bank's output of $i, n$ is the number of banks, Wi as $i$ bank input prices of factors of production, $\mathrm{Zi}$ as a function of exogenous variables, $t_{i}$ as a bank earnings for the banks' cost function of exogenous variables. To achieve a balanced market level, to achieve zero profit constraint is

$$
R_{i}^{*}\left(\mathrm{x}^{*}, \mathrm{n}^{*}, \mathrm{z}\right)-\mathrm{C}_{i}^{*}\left(\mathrm{x}^{*}, \mathrm{w}, \mathrm{t}\right)=0
$$

Variables marked with $*$ are on the equilibrium value. $\mathrm{H}$ PR model uses statistical methods to measure the degree of market structure and competition, $\mathrm{H}$ index is a measure of the income on the investment by the price elasticity size to achieve. Competitive market environment testing $\mathrm{H} \leq 0$ is completely monopolize the market or short-term oligopolistic market completely collusion, market demand is greater than supply $0<\mathrm{H}<1$ monopolistic competition into the free market $\mathrm{H}=1$ perfectly competitive market, a balanced test $\mathrm{H}<0$ non-equilibrium $\mathrm{H}=0$ balanced, $\mathrm{H}$ index values in Table 1 meaning

$$
H=\sum_{k=1}^{m} \frac{\delta R_{I}^{*}}{\delta W_{k i}} \frac{W_{k i}}{R_{i}^{*}}
$$

TABLE I. H INDEX VALUES IN TABLE 1 MEANING

\begin{tabular}{|l|l|}
\hline $\mathrm{H} \leq 0$ & $\begin{array}{l}\text { Complete monopoly or oligopoly market } \\
\text { short-term fully collusion, market } \\
\text { demand is greater than supply }\end{array}$ \\
\hline $0<\mathrm{H}<1$ & $\begin{array}{l}\text { Monopolistic competition into the free } \\
\text { market }\end{array}$ \\
\hline $\mathrm{H}=1$ & Perfectly competitive market \\
\hline $\mathrm{H}<0$ & Unbalanced \\
\hline $\mathrm{H}=0$ & Balanced \\
\hline
\end{tabular}

PR model proposed $\mathrm{H}$ statistic, the total revenue and the elastic input prices.

\section{B. An Empirical Analysis of China's banking sector}

According to Claessens and Laevenp[7, We use PR model to construct econometric models of the China Banking $\mathrm{H}$ values: 


$$
\begin{aligned}
& \ln \left(\mathrm{p}_{\mathrm{it}}\right)=\alpha+\beta_{1} \ln \left(\mathrm{W}_{1, \text { it }}\right)+\beta_{2}\left(\mathrm{~W}_{2, \text { it }}\right) \\
& +\beta_{3} \ln \left(\mathrm{W}_{3, \text { it }}\right)+\gamma_{1} \ln \left(\mathrm{Y}_{1, \text { it }}\right) \\
& +\gamma_{2} \ln \left(\mathrm{Y}_{2, \text { it }}\right)+\varepsilon_{\text {it }} \\
& H=\beta_{1}+\beta_{2}+\beta_{3}
\end{aligned}
$$

Among them: $p_{i t}$ For the ratio of interest income to total assets. Assuming the bank has three inputs, $\mathrm{W}_{1 \text {, it }}$ namely labor inputs, $\mathrm{W}_{2}$, it capital investment and $\mathrm{W}_{3 \text {, it }}$ capital investment, which use the unit price to express. $\mathrm{W}_{1}$, it as human input, because our banking information disclosed in the report were not spending the full cost of the project staff, staff costs and the number of complete employee data is difficult to obtain because of Bikker and Haa replaced with total assets over total employees, here we are with operating expenses and total assets instead, is more than operating expenses to total assets. $\mathrm{W}_{2}$, it as the unit cost of capital, as the ratio of interest expense to total assets. $\mathrm{W}_{3}$, it as Capital investment than the fees and expenses and other operating expenses to total assets. $T$ and the subscript i refer to the time and banking number. $\varepsilon$ it Refers to Random error term, which means that a number of other factors and statistical error and so on. For modern banks, some other factors affecting income, they exist in theory and statistical values of $\mathrm{H}$ intrinsically linked, here select two control variables, $\mathrm{Y}_{1 \text {, it }}$ expressed as a ratio of loans to total assets, $Y_{2}$, it means that the owner ratio of equity to total assets. All of these variables are used in the natural logarithm form.

\section{ANALYSIS OF THE RELATION OF THE BANKING COMPETITION AND RISK}

\section{A. Econometric models and variables Description}

In the above basis, we study the relationship between China and the competition between banks bear the risk of the banking sector. Foreign literature on bank exposures commonly used measure of stock price volatility corresponding to reflect the properties of the sample due to problems, this study clearly want to select a new index to measure the risk incurred by the banks. At present, China's banking industry to implement a risk-based regulatory approach, the proportion of non-performing loans occupies a very important position in risk indicators, is also the focus of banking supervision, so we use the ratio of nonperforming loans (BLDKBL) as a measure of bank risk indicators. Of course, to analyze the relationship between banking competition and bank exposures, but also take into account other factors that affect bank exposures, environmental factors such as market, bank and other individual factors. Taking into account the actual situation in China, based on a measure of banking risk awareness, establish the following model:

$$
B L D K B L_{i t}=\alpha H_{t}+\beta M_{t}+\chi S_{i t}+c
$$

$B L D K B L_{i t}$ is the non-performing loan ratio of $\mathrm{i}$ bank in period $\mathrm{t} ; H_{t}$ is the degree of competition period $\mathrm{t}$; $M_{t}$ is market environment variables which impact bank risktaking that is the same for all banks are over time to changing. paper selects the annual gross domestic product (GDP) to reflect the common market environment factors banking; $S_{i t}$ refer to impact bank exposures, but with time and change banks and banking groups of individual variables, the paper selected banks' total assets (ZZC) and (i.e., the ratio of non-performing loans on the issue of impact) as an alternative variable.

\section{B. The results of empirical testing and analysis}

At the time of the panel data model is estimated using sample data contains the individual indicators, time three aspects of information, if the model form set incorrectly estimated results will be a serious deviation from the economic phenomenon to be simulated. Therefore, we must first examine the model form set. Test is frequently used analysis of covariance test, the main test the following two assumptions ( $\alpha$ is the intercept, $\beta$ is a coefficient):

$$
\begin{aligned}
& H_{1}: \beta_{1}=\beta_{2}=\ldots=\beta_{n} \\
& H_{2}: \alpha_{1}=\alpha_{2}=\ldots=\beta_{n} \\
& \beta_{1}=\beta_{2}=\ldots=\beta_{n}
\end{aligned}
$$

$\mathrm{N}=14$, First calculate the variable parameter model, residual sum of squares variable intercept model and the same parameters of the model case and then calculate the statistic $\mathrm{F}$ (5\% at a given level of significance under), we get:

$\mathrm{F}_{2}=1.4642$

So reject the hypothesis $\mathrm{H}_{2}$, continue to test the hypothesis $\mathrm{H}_{1}$.

$\mathrm{F}_{1}=1.4948$

So accept the assumption $\mathrm{H}_{1}$, the model is set to variable intercept model.

Also, because the only effect of the sample itself as a condition for analysis, we will use the variable intercept fixed effect model estimation. Data relating to the study of macroeconomic and banking come from "China Statistical Yearbook", "China Financial Statistics Yearbook," and the CBRC website.

\section{CONCLUSIONS ANALYSIS AND POLICY RECOMMENDATIONS}

\section{A. Research findings}

(1) Chinese banking is in monopoly competition. The core of the financial sector in the economy requires a healthy banking operations, both to improve the efficiency of the banking sector through competition, but also to maintain stability and security in the banking sector. The reform of China's banking industry has ever yielded good results, mainly in the monopoly broken, increasing the number of family practitioners, an increase of the level of competition, banking service quality and operating efficiency and a more modern sound system gradually established diversified banking organizations, etc.. But whether from domestic or international perspective, reform 
is still far from reaching the ultimate goal : From a domestic perspective, the banking sector remains high degree of monopoly in the market entry and business is still strictly controlled, limited opening degrees of banking organizations many lack of system building; from an international perspective, the overall efficiency of the Chinese banking industry is not high, international competitiveness, the lack of super- powerful multinational banks . Thus, the road to reform China's banking sector needs to keep walking.

(2) Exists significant relationship between banking competition and risk-taking, and even exists positive correlation between the degree of competition in the banking sector and the proportion of the banks' bad loans. The empirical results more supportive Allen and Gale [8], who concluded . In a market economy, diversified financial organization system for their own survival and development, the existence of competitive behaviour objectively, in an attempt to expand the scale of assets to gain advantage, gaining market share and expanding the economic penetration. General point of view, banking competition due to the neglect of comparative costs, with the expansion of the scale of assets, it is possible to make the competition costs, time to bring down the risk that asset quality , liquidity credit delay. These problems have in recent years China's banking reform appears noteworthy.

(3) Banking competition will lead to state-owned banks (large banks) to take greater risks.

We known that in the banking sector external factors in certain circumstances, the degree of banking competition in China bear the risk of impact on the individual level there is a difference of banks. Joint-stock bank has its inherent advantages, such as a more comprehensive system of corporate governance structure of the company, flexible personnel management system, good asset quality, there is no historical baggage and so on. Therefore, the competition in the banking industry, the risk of joint-stock banks to take more flexible than the large state-owned banks to be small.

\section{B. The relevant recommendations}

(1) Further promote the reform of the banking sector. In the process of transition to a market economy, China to build a robust and vibrant banking system, which would further promote the reform, opening wider to achieve functional and institutional restructuring to adjust and improve their internal governance and management transparency, in order to achieve efficient operations. Especially for large commercial banks, to establish an effective corporate governance mechanism, scientific incentive and restraint mechanisms and capital risk control mechanism, competitive environment in a healthy and orderly operation.

(2) Adopt strict market access. Banking market access restrictions for scientific, reduce bank entry decisions blindness and randomness, giving greater flexibility in organization and business access, the degree of market competition will remain at the appropriate level. For those risk control ability of the bank, may be appropriate to relax the barriers to entry; poor risk management and control of banks, institutions may limit its expansion and new business development, to maintain a reasonable and orderly competition in the banking sector, the banking sector to maintain stable operation .

(3) Further enhance the effectiveness of banking supervision. In the absence of good information disclosure and the presence of full government guarantees, increased competition can easily lead to excessive risk-taking behavior of banks. So, first to develop scientific, cautious, standardized, transparent market access standards and operational procedures, maintenance of fair competition in banking, promote financial innovation; Second, through the establishment of sustainable and effective on-site inspection and off-site monitoring system and scientific effective risk assessment, early warning system, and further prevent banking risks ; Third, to further clarify the problematic agency market exit criteria and procedures mechanisms, clear responsibilities of regulatory authorities, to maintain the market order of fair competition .

\section{REFERENCES}

[1] Demsetz, R., Saidenberg, M., and Strahan, P., Banks with Something to Lose: The Disciplinary Role of the Franchise Value, Economic Policy Review, 2(2), pp.1-14, 1996.

[2] Salas, V., and J. Saurina, Credit Risk in Two Institutional Regimes: Spanish Commercial and Savings Banks, Journal of Financial Services Research, 22 (3), pp. 203-24, 2002.

[3] N Cetorelli, M Gambera, Banking market structure, financial dependence and growth: International evidence from industry data, The Journal of Finance, 56 (2), 617-648, 2001.

[4] Beck, T., Demirguc-Kunt, A., and R.Levine, Bank Concentration and Crises, NBER Working Paper, No.9921, 2003.

[5] Canova, Fabio \& de Nicolo, Gianni, On the sources of business cycles in the G-7, Journal of International Economics, Elsevier, 59(1), pp.77$100,2003$.

[6] Boyd, J.H. ,De Nieolo, G, The Theory of Bank Risk Taking and Competition Revisited, Journal of Finance, 60(1), pp. 1329-1343, 2005.

[7] Claessens, S., and Laeven L., What Drives Bank Competition. Some International Evidence, Journal of Money, Credit and Banking, 36(3), pp. 585-92, 2004.

[8] Franklin Allen, Douglas Gale, Comparison of the financial system, China Renmin University Press, 2002. 